cases of cure following posterior operation, nre really bronght ahout hy local and general rest-hy putting patients in such a position that they cannot, hy overexertion of any kind, nake a had matter worse. The retina, having meantime hroken loose from its eonnection with the shrinking vitreous, returns to its normal position, and the trentment, medical or surgical, receives the credit.-Transactiont Section on Ophthalmology, American Medical Association, 1896.

Cocaing in Glancoma.-Gnoexow (Breslau) has no fear as to harm from the employment of cocaine in eyes presenting a glaucomatous condition ( $\mathrm{La}$ Semaine Mredicale, 16 Ann. No. 40). He has never seen it do harm; hut, on the contrary, its use has often heen attended with good results. It diminishes acute pain, lessens the hypersemia, and does not raise the tension of the eyehall. By its mydriatic effect it allows of the hetter examination of the eye.

\title{
OBSTETRICS.
}

\section{UNDER THE CHARGE OF}

EDWARD P. DAVIS, A.MY., MI.D.,

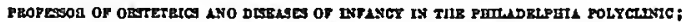

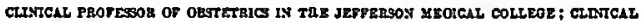

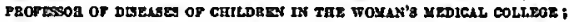

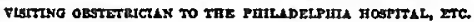

The Choice of Version or Forceps in Moderato Pelvic Deformity.-In the British Sredical Jourual, 1896, No. 1870, is puhlished a paper hy MIILNE Mfornay, in which he adrocates the use of forceps in cases of flattened pelvis in which the head presents transversely in the pelvic hrim. Murray states that the choice of rersion in these cases has heen hased upon the helief that the forceps, applied in the antero-posterior riameter of the head, tends to compress it antcro-posteriorly, and to causc a hulging of the transverse or biparietal diameter. This would increase the difficnlty of extraction, as the hiparietal dismeter is already hrought into relation with the smallest diameter of the pelvie hrim. Marray douhts the truth of this helief, hecause he has shown hy experiment that when the head is grasped over the occiput and forehend that the occipito-frontal diameter may he compressed one and one-half inches without increasing the hiparietal. A vertical and not a transverse expansion results. The various segments of the cranium slide under each other in a telescopic manner.

To succeed in delivering the foral head presenting transversely in the hrim of a flattened pelvis the forceps must not only grasp the head in its antero-posterior dianeter, but must also inake traction downward and hackward in the axis of the pelvis. The head nnturally passes through the hrim, in these eases, hy an exaggeration of Naegele's ohliquity, by which the posterior parietal eminence pivots against the promontory of the sacrum, while 
the anterior moulds itself ngainst the puhes. Mrurray stated that he had delivered living children where the antero-posterior pclvic diameter was three and one-quarter inehes, and even as little as two and threc-quarters inches. To seeure perfect axis-traetion he has attaehed to his foreeps a handle which is movahle npon a right-angled traction-bar; ly this means he ean vary the direction of his traction to suit the ahnormalities of the pelvis.

In discussion, Formerair. and Casrerox agreed essentially with Murray. KERR thought that suecess in sueh extractions was ohtained hy rotating the head ohliquely into one of the ohlique diameters of the pelvie hrim. He thought that it is rare to find the tro halres of a pelvis of equal size, and that in difficult labor the hcad will enter the larger portion of the pelvis. He helieved thnt the head rarely passed through the pelric hrim in a strictly transverse position.

(The editor, from his experienee, is inelined to indorse the views of $\mathrm{Dr}$. Kerr on this question. While it is no doubt possihle to deliver the head in many cases as Dr. Mrurray indicates, still in many others tbo head moulds itself into an irregular, ohliqne position. The suggestion of Dr. Murray that the line of traetion should he strongly hnelward as well as downwnrd is most valuable. In a reeent case, in a flat pelvis where the first ehild had heen lost hy pressure, nod where others und failed with foreeps, sueeess was nehiered hy putting the pntient in Waleher's position nnd hy making traetion in exiggerated downmard nad backwnrd direction. A living ehild was delivered with Simpson's forceps, axis-trnetion heing effected ly the use of tapes.)

Snecessful Cagarean Section npoz a Bhachitic Patient, Performed at Her Home.-In Le Progrex Medicale, 1896, No. 46, Becret report3 the case of $n$ roman, nged thirty-cight years, having a highly eontracted rhaehitic pelris, who had been in lalior at intervals during thee days when he was called to attend her. The head of tho ebild was evideotly large and eould not deseend into the pelvis. The mother was in fair condition, withont infeetion, and her exeretion fairly well performed. Symphysiotomy was declined hecause of the high degree of pelvie contration, nnd the Casarean seetion undertaken. This was performed in the usual manner, the placenta heing found heneath the line of incision and some hemorrhage oecurring when the uterus was opened. This was controlled by injections of ergotin and the application of gauze-pads wrung out of lot, sterile water. The muscle of the uterus nnd its peritoneal covering were sutured separutely and with great care, and the ahdomeu closed. The patient made an uninterrupted recorcry. This case illustrates the fact that the Casarean seetion may he successfully performed without the advantages afforded hy a hospital.

Studies in the Blood of the Newborn.-In the 1Viener klinische Wochenschrift, 1896, Nos. 41 and 43 , are pnhlished two vcry interesting papers, one upon "Mrelrena" and the other upon the "Condition of the Red Blood-cells in Cases of Icterus Neonatorum." The first paper is hy Swo BodA, one of the physicians to the Vienna Foundling Asylum. In this paper he narrates n number of cases of infants dying with passire hemorrhages from the nose, 
mouth, and intestinc. In a numher of these post-mortem examination rcrenled the lesions of congenital syphilis. In others septie infeetion occhsioned by the gonococcus was the primary cause of the bleeding. In others a meniagitis had dereloped withont lesions of eyphilis. No cause other than a mechanical one from pressure upon the head, or excessive coughing or straining, could he found for the condition. He also repurts several cases of bleeding from the nose in in fants, in which bacteriological examination showed the presence of tho bacillus of diphtheria as a cause. His interesting paper serves to illustrate the fact that melæna is n symptom only, whose cause must always be sought before the pathology or trentment of a given case becomes evident.

Kroepfenaracnen has stulicd the icterus of the uerborn, and the rclation which the condition of the red blood-cells hears to this phenomenon. His conclusions are essentially as follows: in the first weeks of life the number of red blood-eels is not influenced by a condition of icterus. Variations in the number of rcd corpuscles depend upon changes in the quantity aad quality of the blood-plasma. The resisting power of the red eorpuscles at birth seems to he fully that possessed by these cclls in the adult, and does not seem to be lessened hy icterus, however intense. The microscopie examination of tho blood of the newborn in these cases shows, during the first days of life, no sign of erythroeytes, but, on the contrary, gives only indications of a vigorous building-up of red hlood-cells. The eonclusion of these studies is in general that the eondition of ieterus in tho newhorn does not influenee esseutially the red blood-eells.

Purpura Hemorrhagica in a Newborn Child with Congenital Syphilis.In the Revue Mensuelle des Mriladies de I Enfance, November, 1896, JoLLy reports the ease of an infant, nineteen days old, who died of purpura hemorrhagica, in whom autopsy showed intestinal ulceration and lesions eharaeteristic of congcaital syphilis. Other possihle causes of theso phenomena were earefully exeluded in making a diagnosis.

The Use of the Phonendoscope in Ohstetrie Diagnosis.-In the Prager medicinische Wochenschrift, 1896, No. 46, KNipP reports his observations in the use of this instrument. He agrees with Prubrass in the value of the instrument, and has found it especially useful in diagnosticating twin pregnancy, and also in deteeting coiling of the cord about the foetus. When a murmur can he located over the foetus a little slower than the featal pulse, but more rapid than the maternal aorta, nod differentiated from the plucental bruit, a diagnosis of coiling of the cord nbont the foetus may he considered as rcasonahly certain. In twin-pregnaney the two heart-sounds may he more readily diagnosticated hy this means. The location of the placenta can also be ascertained hy the usc of the phonendoscopc.

Symphysiotomy,-In the Edinburgh Bfedical Journal, Decemher, 1896, Dosald reports threc symphysiotomies. The first was upon a multipara who had bornc five children, four of them stillborn. A general contraction of the pelvis is said to have heen present, with a true eonjugate of threc and onc-quarter inches. The patient was admitted to the hospital in the second 
stage of labor, and no progress was made for three hours, although the pains were gtrong. The joint was opened by an iaeision ahove the pubes, the joiatsurfaces separating nearly an ineh. The hend was adjusted to the brim and ensily delivered hy axis-traction forceps. The extent of separation during delivery was about two and one-half iaches. The ehild was of arcrage size, and a healthy female. Buried silk sutures were employed in the periosteum and the skia was closed with silkworm-gut. The pelvis was strapped, a firm baadage applied, and sandbags placed oa each side of the pelvis. The patieat left the hospital nt the end of six weeks in good condition.

Case II. was in her second labor, the first haviag heen termianted by the hirth of a stillhorn child with foreeps. The pelvis was of the same type as the preceding. She was admitted to the hospital, haviag heea ia lnbor for twenty-four hours. The eervir was widely dilated, the hend not engaged, the heart-sounds distiact. After symphysiotomy the delivery was diffieult, the bones separating fully two and three-quarters inches. A living female ehild of average size was extraeted. The patient's convaleseeace was somewhat hindered hy swelling and suppuration of tbe lahia. The patient was up in four weeks, and the final resnlt was good.

Case III. Was a multipara who had lost six children through embryotomy, premsture labor, and tedious spontaneous labor. The true conjugate was three and one-quarter inches. Pntient ndmitted to hospital in labor, the membranes having ruptured sixty hours hefore admission. As dilatation was hut partly complete, de Ribes's bag was employed. The pubes separated about two inches during delivery. A puny male child was born, which required resuscitation. Patient got up in niaeteen days, but was lept in hospital on account of the illness of the child. The infant developed congenital syphilis nad died three months after birth.

In the Botion Stedical and Surgical Journal, December 17, 1896, SwrFr reports the first symphysiotomy performed in Boston or vieinity. The patieat was in her second labor, haviog beea delivered of her frst child hy craniotomy. The patient had been in Inhor nbout twenty-four hours; the os was fully dilated and the memhranes ruptured. The pelvis was symmetrically contrueted, the external conjngate beiag seven and oae-half isehes. The trne eosjugate was estimated at about three inebes. The patient was triea to a hospital and symphysiotomy performed hy suprnpnbic ineision. The patient was delivered hy foreeps, the pubie bones sepnratiag ahont one nnd ose-half iaches. The child was resuseitated without diffieulty. The pelvis was bronght together by firm preasure, asd a heavy silk suture passed throngh the hones, a wire suture haviag hrokea. The pelvis was fixed hy a broad band of adhesive plaster. A self-retaining catheter was placed in the bladder. The ineision healed on the fifth dny, and abscess formed in the lise of incision. This was readily emptied, and occasioned but slight disturhance. The patient nursed her child. In the discussion whieh followed the report of this case the balance of opiaion was in favor of Casarena section as being the less dangerous and more feasible operation. It was recogaized that a field for symphysiotomy exists in well-chosen cases.

Is the Mfedical News, Jasuary 16, 1897, the writer reported a symphysiotomy, performed is Jannary, 1896, npoa a patieat whose first ehild had 
becn delivered with difficulty by forceps. This child survived. Spontaneous labor in tbe sccond instance had failed, and the physician in attendance had not succecded in delivering with forceps. The hend was bnt partially cngaged; the heart-sounds werc very rapid. The pelvis was symmetrical in contour, but contracted in all its dinmeters from one-half to tro $\mathrm{cm}$. Tbe ground for symphysiotomy was disproportion between the pelvis and the foetus, due not only to the pelvic contraction, hut to the incrense in the size which the foetus displays in repented pregnancy. Tbe heart-sounds of the fetus were very rapid, hut distinct. Symphysiotomy was performed by suprapubic incision, the joint being readily opened with a bistoury. The occiput rotated posteriorly, and the child was delivered with axis-traction forceps. It was a male, weighing eigbt ponnds, its mensurements in several of the diameters of its hend being from one-half to one $\mathrm{cm}$. above the nveragc. A very perceptible odor was noticed when the child was delivered; it survived eightecn hours, perishing from inspiration-pneumonia. The mother developed sapramia, but madc a good recovery. A slight discharge of sanious fluid issued from the incision for several days. Sbe madc a complete recovery and left the hospital seven weeks after admission. Subsequent mensurement of her pelvis sbowed an increase in its diameters of one-half $\mathrm{cm}$. One yenr after operation she was in excellent henlth, never having experienced the slightest inconvenience from the condition of the pelvis. Sound union in the pubes followed the operation.

\section{- GYNECOIOGY.}

UNDER THE CHARGE OF

HENRY C. COE, M.D., M.R.C.S., · OF NEW YORK.

Etiology and Treatment of Cancer of the Uterns.-BAECKEn (Archiv für Gynākologie, Band liii. He̊t 1), from an analysis of 705 cases of cancer of the uterus, arrives at the following conclusions with reference to the etiology of tbe disease:

1. Tbe truc origin of malignant disease of the oterus is as yct unknown, nor can it be referred to a specific micro-organism. 2. Tbe indirect causc is cndometritis, gencrally of puerperal origin, which furnishes a suitable nidus for its development. This is shown by the fact that cancer is common in women who have borne children, while it is comparatively rare in single and in sterile women, as wcll as in those who have had gonorrhces. Mforeover, in nearly every case of cancer there is a ehronic catarrh of the endometrium. Endometritis is the primary condition, malignant degeneration being secondary. Hence the practical importance of trenting endometritis actively from the outset as a prophylactic measure.

In the trentment of carcinoma of the cervix total extirpation is always 